\title{
Adsorption of Aqueous As (III) in Presence of Coexisting Ions by a Green Fe-Modified W Zeolite
}

\author{
Adriana Medina-Ramirez ${ }^{1, *}$, Procoro Gamero-Melo ${ }^{\mathbb{D}}$, Beatriz Ruiz-Camacho ${ }^{1}$, \\ Jesus Isaac Minchaca-Mojica ${ }^{1}$, Rafael Romero-Toledo ${ }^{1}$ and Karen Yazmin Gamero-Vega ${ }^{2}$ \\ 1 Chemical Engineering Department, Division de Ciencias Naturales y Exactas, Universidad de Guanajuato, \\ Campus Guanajuato, Noria Alta s/n Z.P., 36050 Guanajuato, Mexico; beatriz.ruiz@ugto.mx (B.R.-C.); \\ jminchaca@ugto.mx (J.I.M.-M.); r.romerotoledo@ugto.mx (R.R.-T.) \\ 2 Sustainability of the Natural Resources and Energy, CINVESTAV Saltillo, Av. Industria Metalurgica 1062, \\ Parque industrial Saltillo, 25900 Ramos Arizpe, Mexico; pgamero@cinvestav.mx (P.G.-M.); \\ karengamerov@hotmail.com (K.Y.G.-V.) \\ * Correspondence: adriana.medina@ugto.mx; Tel.: +52-(01)-473-732-0002
}

Received: 1 January 2019; Accepted: 1 February 2019; Published: 6 February 2019

check for updates

\begin{abstract}
The high toxicity of arsenite and the difficulty to remove it is one of the main challenges for water treatment. In the present work the surface of a low cost zeolite was modified by chemical treatment with a ferrous chloride to enhance its arsenite adsorption capacity. The effect of $\mathrm{pH}$, ions coexistence, concentration, temperature and dosage was studied on the adsorption process. Additionally, the Fe-modified $\mathrm{W}$ zeolite was aged by an accelerated procedure and the regeneration of the exhausted zeolite was demonstrated. The Fe-modified $\mathrm{W}$ zeolite was stable in the $\mathrm{pH}$ range of 3 to 8 and no detriment to its arsenite removal capacity was observed in the presence of coexisting ions commonly found in underground water. The studies showed that the adsorption of As (III) on Fe-modified $\mathrm{W}$ zeolite is a feasible, spontaneous and endothermic process and it takes place by chemical bonding. The exhausting process proved the adsorption of $0.20 \mathrm{mg} \mathrm{g}^{-1}$ of As (III) by the Fe-modified $\mathrm{W}$ zeolite and this withstand at least five aging cycles without significant changes of its arsenite adsorption capacity. Fe-modified $\mathrm{W}$ zeolite prepared from fly ash might be a green and low-cost alternative for removal of As (III) from groundwater.
\end{abstract}

Keywords: arsenic; removal; zeolite; green products; heavy metals; recycling; fly ash

\section{Introduction}

Exposure to arsenic (As) through drinking water has been reported to be associated with diverse diseases, for instance adverse pregnancy outcomes and many types of cancer [1-3]. There is strong evidence that chronic inorganic arsenic ingestion increases the risk to developing cardiovascular diseases, diabetes mellitus and damaged cognitive function in early childhood [4,5]. Diabetes has been investigated in arsenic-exposed Mexican populations by Del Razo et al. who found that the prevalence of diabetes was associated with arsenic in drinking water and with the concentration of dimethylarsenite in urine, linking the risk of diabetes to the production of one of the most toxic metabolites of inorganic arsenic [6]. Even low arsenite concentrations $\left(0.002-0.025 \mathrm{mg} \mathrm{L}^{-1}\right)$ in drinking water might increase the risk of myocardial infarction [7] and affect the female fecundity [8]. Cheng et al. found a relation between exposure to arsenic and chronic kidney disease in Taiwan [9]. According to recent reports the arsenite toxicity is due to its interaction to cysteine residues in proteins [10].

The "La Laguna" region in North-Central Mexico, in the states of Durango and Coahuila, presents problems related to the high arsenic content in underground water [11,12]. In different regions of Mexico $[13,14]$ sources of drinking water exceed $0.05 \mathrm{mg} \mathrm{L}^{-1}$ of total As present, higher than the 
maximum concentration of arsenic recommended by the World Health Organization $\left(0.01 \mathrm{mg} \mathrm{L}^{-1}\right)$ and the Mexican Norm $\left(0.025 \mathrm{mg} \mathrm{L}^{-1}\right)$ in drinking water [15]. A study carried out in Sonora, Mexico about the presence of arsenic in water, soil and urine of children exposed, indicated that the $56 \%$ of the wells presented arsenic levels higher than $0.01 \mathrm{mg} \mathrm{L}^{-1}$, while the arsenic detected in soil was of $27 \mathrm{mg}$ of As per kilogram. These findings were associated to high potential risk to developing chronic diseases including cancer in the children exposed [16]. A lower drinking-water exposure concentration of approximately $0.10-0.15 \mathrm{mg} \mathrm{L}^{-1}$ was estimated to result in a concentration of trivalent arsenical species in bladder cells that would be sufficient to exert toxic effects and thereby increasing the risk of cancer [17].

Different techniques have been used to remove arsenic from water such as coagulation, chemical precipitation, the membrane process and adsorption. For the adsorption process, the use of efficient and low-cost adsorbents is one of the main challenges. The adsorption of arsenic species depends on two main factors: (a) the adsorbent surface chemistry and (b) the aqueous phase chemistry [18]. The degree of adsorption of arsenic strongly depends on the chemical nature of the As species, which depends on solution conditions, especially $\mathrm{pH}$ [19]. Arsenic can exist in the form of arsenite and arsenate and under an atmospheric oxidant environment the predominant species is As $(\mathrm{V})$, which in the $\mathrm{pH}$ range of 6-9 exists as deprotonated oxyanion. Under mildly reducing conditions, As (III) is thermodynamically stable and exists as an uncharged specie at $\mathrm{pH}$ below 9 [20,21]. As (III) is more toxic and more difficult to adsorb and to desorb than As (V). So, the As (III) must be removed or oxidized before or during As (V) adsorption process. Different alternatives have been investigated for the oxidation of arsenite and the enhancement of its adsorption on a specific material such as iron and manganese. Oxidant agents such as hydrogen peroxide, chlorine, potassium permanganate, ozone, oxygen, chlorine dioxide, monochloroamine and sodium hypochlorite have been reported. Additionally, other methods have been explored such as photochemical oxidation, photocatalytic oxidation, biological oxidation and in situ oxidation [22-24]. Particularly oxides, hydroxides and oxyhydroxides of iron have exhibited a high affinity for arsenic species. The incorporation of iron to adsorbent surfaces enhances oxidation/adsorption processes that allow reducing costs [25]. Particularly Gallios et al. [26] prepared $\mathrm{Fe}, \mathrm{Fe}-\mathrm{Cu}$ and $\mathrm{Fe}-\mathrm{Mn}$ impregnated carbons which were able to remove in a simultaneous way organic compound and arsenic. Mahmood et al. [27] used Fe-impregnated activated carbon for adsorption of As (III) and found that this material exhibits an arsenite removal three times higher than activated carbon. Montero et al. [28] reported that Fe-coated biochars were efficient for As (III) removal. Additionally, Katsoyiannis et al. [29] reported that pre-polymerized coagulants such as poly-ferric sulphate was effective to remove As (III).

The oxidation state of iron determines the process involved, in the case of Fe (0) and Fe (II) they facilitate the role in oxidation by oxygen or hydrogen peroxide [19].

Anion adsorption on metal-modified zeolites has been studied with $\mathrm{Cr}$ or As oxyanions, exhibiting successful results. Metal modification of zeolites can be carried out by ionic exchange, where cations exhibit affinity for oxyanions. The metal cation acts as a precipitating agent or oxidant/reductant species in the zeolite enhancing the removal of oxyanions [30]. Nevertheless, the ion-exchange capacity of zeolites depends on the framework structure, ion size and shape and ionic charge and concentration of the external electrolyte solution [31]. Some natural [32-35] and synthetic zeolites [36-38] have been modified with iron and evaluated for arsenic adsorption, however, studies of the adsorption of As (III) by Fe-modified zeolites are scarce [39,40].

In the present work, the effect of $\mathrm{pH}$, temperature, concentration, adsorbent dose and ion competition on the adsorption process of As (III) on Fe-modified W zeolite was studied. Additionally, kinetic and thermodynamic studies of As (III) adsorption on this zeolite were carried out. Furthermore, the ageing, desorption and regeneration of the zeolite were also investigated. Finally, a green metric was applied to the synthesis of the Fe-modified $\mathrm{W}$ zeolite and the E-factor, cost parameter and the Eco-Scale were evaluated. 
The $\mathrm{W}$ zeolite synthesized by a green procedure from an industrial by-product with no commercial value and exchanged with Fe (II) ions resulted to be an active specie potentially useful in the formulation of reusable adsorbents able to trap the As (III) contained in underground water.

\section{Materials and Methods}

\subsection{Materials}

The typical properties of Mexican fly ash (MFA) used as source of alumina and silica to synthesize the W zeolite are reported Medina et al. [41]. Ferrous chloride $\left(\mathrm{FeCl}_{2}, 99 \%\right)$ was used to exchange the potassium ions on the $\mathrm{W}$ zeolite surface to ferrous ions. Arsenic solutions were prepared by dissolution of sodium arsenite $\left(\mathrm{NaAsO}_{2}, 98 \%\right)$ in deionized water. Salts of calcium $\left(\mathrm{CaCl}_{2}, 99 \%\right)$, sodium $(\mathrm{NaCl}$, 99\%) and magnesium $\left(\mathrm{MgSO}_{4}, 99 \%\right)$ were used for competing ions evaluation. All reagents used were of reagent grade (by Sigma-Aldrich).

\subsection{Synthesis and Modification of the W Zeolite Surface}

The $\mathrm{W}$ zeolite was synthesized according to the procedure described by Medina et al. [42]. Here, a brief description is provided: $160 \mathrm{~g}$ of MFA was added to $480 \mathrm{~mL}$ of $\mathrm{KOH}$ solution, maintaining a $\mathrm{KOH} / \mathrm{MFA}$ weight ratio of 0.33 , The $\mathrm{pH}$ value of the mixture was 13.7. The resultant reaction mixture was hydrothermally treated at $175^{\circ} \mathrm{C}$ for $16 \mathrm{~h}$. The zeolite was recovered by filtration and washed with deionized water. The product was dried at $110{ }^{\circ} \mathrm{C}$ for $12 \mathrm{~h}$ in an open atmosphere, yielding $197 \mathrm{~g}$ of W zeolite. This is $23.1 \%$ (wt.) more $\mathrm{W}$ zeolite than the amount of MFA used as raw material. The yield of $\mathrm{W}$ zeolite corresponds to $92.6 \%$ related to the total of solid used raw materials.

The modification process of the $\mathrm{W}$ zeolite was carried out as follows: $10 \mathrm{~g}$ of $\mathrm{W}$ zeolite were added to a solution of $\mathrm{FeCl}_{2} 18.6 \mathrm{mM}$. The resultant slurry was kept under stirring at room temperature for $24 \mathrm{~h}$. Subsequently, the modified zeolite was washed with deionized water and dried at $110{ }^{\circ} \mathrm{C}$ for $12 \mathrm{~h}$. The zeolite was labelled as Fe-modified W zeolite.

\subsection{Batch Adsorption Experiments}

Unless otherwise stated a volume of $100 \mathrm{~mL}$ of As (III) solution $0.5 \mathrm{mg} \mathrm{L}^{-1}$ and a dose of $1 \mathrm{~g}$ of zeolite were used in the experiments. The dose was selected considering the solid/liquid ratio (in $\mathrm{g} \mathrm{L}^{-1}$ ) reported by Jimenez et al. [43]. The arsenite adsorption efficiency on the Fe-modified $\mathrm{W}$ zeolite was evaluated in the $\mathrm{pH}$ range of 3 to 10 . An adsorbent/solution ratio 1:10 $\left(\mathrm{g} \mathrm{L}^{-1}\right)$ was used with an initial concentration of $0.5 \mathrm{mg} \mathrm{L}^{-1}$ at $25^{\circ} \mathrm{C}$ for $8 \mathrm{~h}$. Afterwards, the As (III) residual concentration was determined.

\subsubsection{Competing Ions}

The experiments of competing ions were carried out as follows: A solution of As (III) with a concentration of $0.5 \mathrm{mg} \mathrm{L}^{-1}$ was prepared. Then the corresponding amount of metallic salt was added to a $100 \mathrm{~mL}$ of the previously prepared solution of As (III) into an Erlenmeyer flask while stirring. For calcium, magnesium and sulphates ions: 100,500 and $1000 \mathrm{mg} \mathrm{L}^{-1}$; for chloride and carbonate: 100, 300 and $500 \mathrm{mg} \mathrm{L}^{-1}$. Once the salt was dissolved $0.5 \mathrm{~g}$ of zeolite was added and the slurry was stirred for $8 \mathrm{~h}$ at $25^{\circ} \mathrm{C}$. Afterwards, an aliquot of $10 \mathrm{~mL}$ was taken and the residual arsenic concentration was determined.

\subsubsection{Effect of Temperature, Fe-Modified W Zeolite Dose and As (III) Concentration}

Two isotherms models were evaluated for As (III) adsorption on Fe-modified W zeolite: Langmuir and Dubinin Radusckevich (DR). For thermodynamic parameters enthalpy, entropy and Gibbs free energy were determined by using Van't Hoff's equation. The kinetic study was performed by using pseudo-first and pseudo-second order models. To generate the data required for the models parameters 
such as temperature $\left(15,25\right.$ and $\left.35^{\circ} \mathrm{C}\right)$, initial concentration $\left(8.5,4,0.815\right.$ and $\left.0.117 \mathrm{mg} \mathrm{L}^{-1}\right)$ and doses (0.0-1.2 g) were evaluated. The adsorption trials were maintained under stirring for $18 \mathrm{~h}$.

The main difference between Langmuir and DR isotherms model is that Langmuir considers that surface of adsorbent possesses a finite number of identical sites, while DR model does not assume a homogeneous surface. Additionally DR model allows to determine the mechanism involved in the adsorption process through the calculation of the free energy change $(E)$ when one mole of ion is transferred from an infinite solution to the surface of a solid. Moreover the efficiency of the adsorption is determined by the magnitude of dimensionless parameter $r$.

The Langmuir isotherm is expressed by the equation [44]:

$$
\left(\frac{1}{q}\right)=\left(\frac{1}{b q_{m} C_{e}}\right)+\left(\frac{1}{q_{m}}\right)
$$

where $q$ and $C_{e}$ are the equilibrium adsorption capacity $\left(\mathrm{mg} \mathrm{g}^{-1}\right)$ and the equilibrium solute concentration $\left(\mathrm{mg} \mathrm{L}^{-1}\right)$, respectively. $b$ and $q_{m}$ represent the energy adsorption $\left(\mathrm{L} \mathrm{mg}^{-1}\right)$ and adsorption capacity $\left(\mathrm{mg} \mathrm{g}^{-1}\right)$.

In case of DR isotherm the following equations are required [45,46]:

$$
\begin{gathered}
\ln Q=\ln Q_{\max }-k \varepsilon^{2}, \\
\varepsilon=R T \ln \left(\frac{C_{0}}{C_{e}}\right), \\
E=(-2 k)^{\frac{1}{2}}, \\
r=\frac{1}{a+b C_{0}},
\end{gathered}
$$

where $Q$ is the quantity of arsenite adsorbed per unit of mass of zeolite $\left(\mathrm{mg} \mathrm{g}^{-1}\right), Q_{\max }$ is the adsorption capacity $\left(\mathrm{mg} \mathrm{g}^{-1}\right), \varepsilon$ is the Polanyi potential, $C_{0}$ and $C_{e}$ are the initial and equilibrium arsenite concentration ( $\left.\mathrm{mg} \mathrm{L}^{-1}\right), k$ is a constant related to adsorption energy and $b$ is the Langmuir constant.

The Van't Hoff's Equations (6) and (7) are useful to determine the thermodynamic parameters. It assumes that Langmuir constant $b$ and enthalpy adsorption are function of the specific pair of adsorbent ions on the active site and on the temperature [47].

$$
\begin{aligned}
& b=K_{L}=\left[\frac{-\Delta G^{\circ}}{R T}\right], \\
& \ln K_{L}=\frac{\Delta S^{\circ}}{R}-\frac{\Delta H^{\circ}}{R T},
\end{aligned}
$$

where $K_{L}$ is the equilibrium constant.

The adsorption rate constant $\left(k_{1}\right.$ or $\left.k_{2}\right)$ was determined evaluating the data with the equations of pseudo-first (Equation (8)) and pseudo second order (Equation (9)) $[48,49]$. While the mass transfer coefficient $(\beta)$ was obtained using the Equation (10) proposed by Mckay et al. [50]:

$$
\begin{gathered}
\ln \left(q_{1}-q_{t}\right)=\ln q_{1}-k_{1} t \\
\frac{t}{q_{t}}=\frac{t}{k_{2} q_{2}}+\frac{t}{q_{2}} \\
\ln \left(\frac{C_{t}}{C_{o}}-\frac{1}{1+M K_{b q}}\right)=\ln \left(\frac{M K_{b q}}{1+M K_{b q}}\right)-\left(\frac{1+M_{b q}}{M K_{b q}}\right) \beta S_{s} t,
\end{gathered}
$$

where $C_{t}$ is the arsenite concentration at time $t\left(\mathrm{mg} \mathrm{L}^{-1}\right), K_{b q}$ is the result obtaining of multiplying of Langmuir constants $\left(q_{m}\right.$ and $\left.b\right), M$ is the mass of the adsorbent per unit volume of particle free 
adsorbent solution $(\mathrm{g} / \mathrm{L})$ and $S_{s}$ is the external surface area of adsorbent per unit volume of particle free slurry $\left(\mathrm{cm}^{-1}\right)$.

\subsection{Ageing, Desorption and Regeneration of Fe-Modified W Zeolite}

An important feature of adsorbent materials is the possibility to be regenerated and reused, allowing reduction of costs and increasing their efficiency. For this reason, the modified zeolite was exposed to accelerated ageing, desorption and regeneration processes. Two concentrations of As (III) solution, 0.2 and $1 \mathrm{mg} \mathrm{L}^{-1}$.were evaluated for ageing process of the Fe-modified $\mathrm{W}$ zeolite.

This accelerated ageing process consists of the addition of $1 \mathrm{~g}$ of the Fe-modified $\mathrm{W}$ zeolite to an arsenic solution stir for $15 \mathrm{~h}$ at room temperature in an open atmosphere. After this time an aliquot of $10 \mathrm{~mL}$ was taken to determine the residual arsenic concentration. The Fe-modified $\mathrm{W}$ zeolite was recovered, filtered and dried at under an open atmosphere. Then the modified zeolite was again exposed to the batch adsorption in a fresh arsenic solution. The procedure was repeated three times for high arsenic concentration and seven times for low arsenic concentration.

For desorption studies, the modified zeolite recovered from the last adsorption cycle was added to $100 \mathrm{~mL}$ of a solution of $\mathrm{NaOH} 0.1 \mathrm{M}$ and stirred for $4 \mathrm{~h}$. After this time an aliquot of $10 \mathrm{~mL}$ was taken, passed through syringe filter and analysed by plasma emission spectrophotometry to determine the desorbed arsenic concentration. The Fe-modified W zeolite was recovered, washed and dried under open atmosphere.

The regeneration of the active sites of the zeolite was performed by following the same procedure to modify the zeolite (described above). The adsorption capacity of the regenerated Fe-modified $\mathrm{W}$ zeolite was verified by using an As (III) solution $\left(1 \mathrm{mg} \mathrm{L}^{-1}\right)$ and kept under stirring for $15 \mathrm{~h}$.

\subsection{Green Metric for W Zeolite Synthesis}

To evaluate the sustainability and the green chemistry of the synthesis method of $\mathrm{W}$ zeolite from fly ash, the Eco-Scale, Environmental factor (E-factor) and cost factor were applied. The green metric was performed comparing the obtaining of $\mathrm{W}$ zeolite from fly ash and from precursors of analytical grade. According to the Eco-Scale method proposed by Van Aken et al. there are ecological and economical parameters involved in greener and sustainable processes [51]. Although this method was designed for organic synthesis, it can be useful for inorganic synthesis. Pini et al. implemented the Eco-scale method for synthesis of $\mathrm{TiO}_{2}$ nanoparticles [52]. Galuzka et al. used this method for analytical procedures assessment [53]. In the present work the prices of reagents required for cost parameter were taken from an online catalogue of Sigma-Aldrich. The quantity of reagent corresponded to the amount used during the synthesis of $\mathrm{W}$ zeolite at laboratory scale. For Eco-scale, the safety parameter was determined according to the procedure reported by Galuzka et al. which involves the number of pictograms and the signal word indicated for each reagent [53].

\subsection{Characterization Techniques}

The crystalline phases were determined by X-ray diffraction (XRD) using a Philips model XPert PW3040 diffractometer. The morphology of the W zeolite was examined by Scanning Electron Microscopy (SEM) using a Philips XL30 ESEM microscope. The chemical composition was measured by X-ray Fluorescence (XRF) using a Bruker AXS spectrometer model S4 PIONEER. The concentration of residual As (III) was measured by plasma emission spectrophotometry (Thermo Elemental Instrumental, Iris Intrepid II) according to ASTM standard E-1097-07. Textural properties were determined by Autosorb 1C equipment, Quantachrome Instruments. The nitrogen adsorption isotherms were determined at $-196^{\circ} \mathrm{C}$. The samples were degassed at $300{ }^{\circ} \mathrm{C}$ before analysis. 


\section{Results and Discussion}

\subsection{Fe-Modified W Zeolite Characterization}

Figure 1a shows the XRD patterns of the pristine $W$ zeolite and Fe-modified $W$ zeolite, which were obtained as unique crystalline phase corresponding to Lynde W (JCPDS 86-1110), there were no significant changes as consequence of ionic exchange treatment. The Si/Al ratio of the Fe-modified $\mathrm{W}$ zeolite was 2.04. The Raman spectra (Figure 1b) of the pristine and the modified W zeolites shows the characteristic peaks of the zeolitic materials. The most intense bands correspond to the region of 300-600 $\mathrm{cm}^{-1}[54,55]$. The band [54] at $295 \mathrm{~cm}^{-1}$ is associated to motion of an oxygen atom in a perpendicular plane to $\mathrm{T}-\mathrm{O}-\mathrm{T}$ bonds $\left(\mathrm{T}=\mathrm{Si}\right.$ or $\mathrm{Al}$ ) while the bands at 414 and $423 \mathrm{~cm}^{-1}$ corresponding to vibration mode of tetrahedral in the network [56]. The bands around $500 \mathrm{~cm}^{-1}$ are associated to zeolites with even- number rings [54], in this case W zeolite structure possess 8-member rings. The variation in the frequency of the bands is due to the nature of cations [55]. Additionally to these bands, in Fe-modified $W$ zeolite new bands at 615 and $671 \mathrm{~cm}^{-1}$ were detected, they could be associated to the presence of the iron in the zeolite, considering that the only difference between the pristine and the modified zeolites is the chemical composition. Similar results were observed by Yu et al. in Fe-ZSM5 zeolite [57].
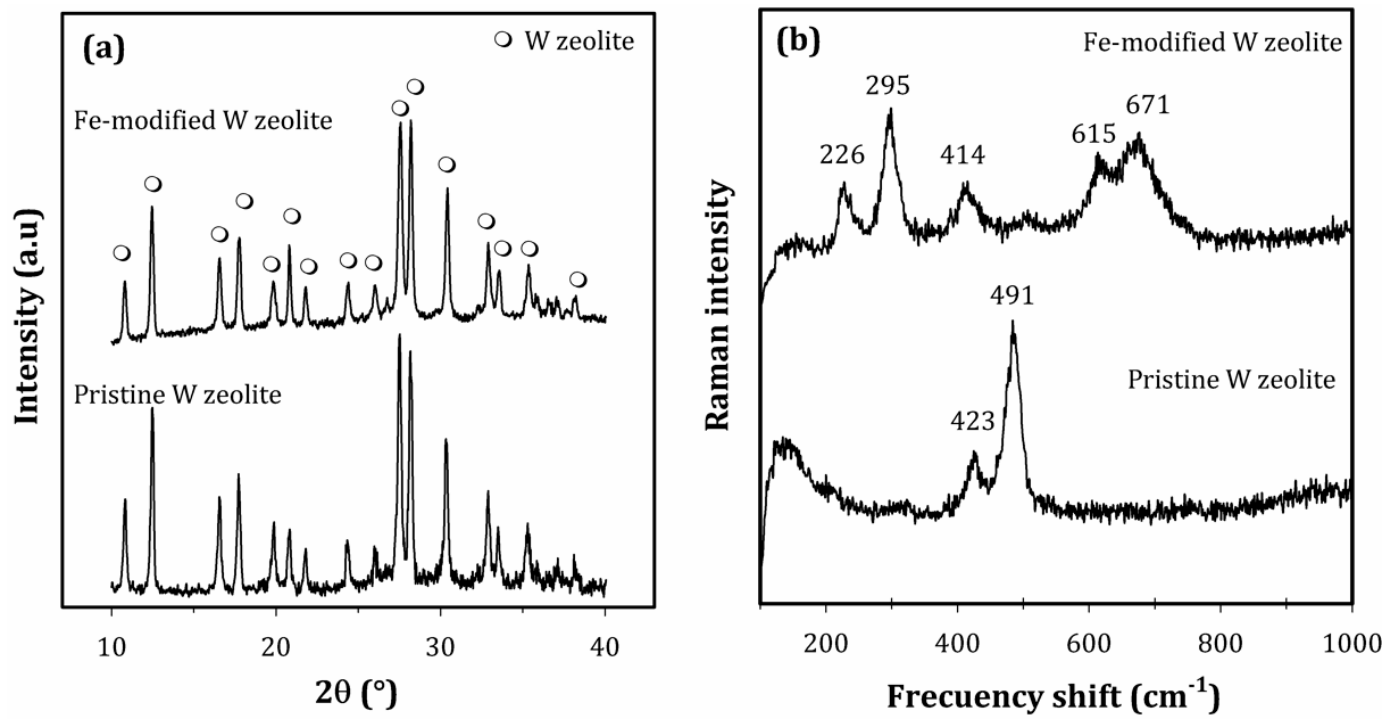

Figure 1. (a) XRD patterns and (b) Raman spectra of the pristine and Fe-modified W zeolite.

According to the SEM analysis (Figure 2a,b) the W zeolite has a morphology of pseudo-spherical aggregated of long needle-like crystals. The $\mathrm{W}$ zeolite has been obtained as long needle-like crystallites and elongated crystals [58,59]. In the EDS spectra of Fe-modified W zeolite (Figure 2d) was noticed that signal corresponding to potassium was decreased while the iron signal increased in comparison to those observed in pristine W zeolite (Figure 2c). Additionally, the samples were analysed by XRF where the chemical composition of pristine $\mathrm{W}$ zeolite was: $\mathrm{SiO}_{2}(43.43 \%), \mathrm{Al}_{2} \mathrm{O}_{3}(17.92 \%), \mathrm{K}_{2} \mathrm{O}(15.09 \%)$, $\mathrm{Na}_{2} \mathrm{O}(0.20 \%) ; \mathrm{F}_{\mathrm{e} 2} \mathrm{O}_{3}(3.97 \%), \mathrm{CaO}(2.61 \%), \mathrm{TiO}_{2}(0.72 \%)$, LOI (16.06\%) while the Fe-modified W zeolite composition was: $\mathrm{SiO}_{2}(43.32 \%), \mathrm{Al}_{2} \mathrm{O}_{3}(17.56 \%), \mathrm{K}_{2} \mathrm{O}(12.83 \%), \mathrm{F}_{\mathrm{e} 2} \mathrm{O}_{3}(8.82 \%), \mathrm{CaO}(0.87 \%), \mathrm{TiO}_{2}$ $(0.73 \%)$, LOI $(15.73 \%)$. This behaviour is indicative that the sodium, calcium and potassium, were exchanged by iron during modification treatment. This result agrees with the one observed by Raman spectroscopy where new bands appeared after ionic exchange with the iron salt. Additionally, as a result of modification with ferrous ions the textural properties were modified. The specific surface area increased $\left(45.76 \mathrm{~m}^{2} / \mathrm{g}\right)$ with respect to its unmodified zeolitic form $\left(\mathrm{K}-\mathrm{W}, 28.48 \mathrm{~m}^{2} / \mathrm{g}\right)$. The average pore size decreased from $18.52 \mathrm{~nm}$ to $12.12 \mathrm{~nm}$ for the $\mathrm{K}-\mathrm{W}$ zeolite and the Fe-modified $\mathrm{W}$ zeolites, respectively. This behaviour is related to the difference between ionic radii of $K(\mathrm{I})(1.33 \AA$ ) and Fe(II) 
$(0.76 \AA)$. No relevant changes were observed for the pore volume before $\left(0.132 \mathrm{~cm}^{3} / \mathrm{g}\right)$ and after the functionalization process $\left(0.139 \mathrm{~cm}^{3} / \mathrm{g}\right)$. The adsorption isotherm of the Fe-modified $\mathrm{W}$ zeolite corresponds to type Ilb. These type isotherms are obtained with aggregates of plate-like particles which possess non-rigid slit-shaped pores [60]. The adsorption isotherm presented hysteresis loop which belongs to type H3. It was observed that the hysteresis loop was more pronounced compared to those of pristine zeolite. This indicates that the modified zeolite exhibits more mesoporosity which is related to the decrease in the pore size. According to Lowell when an increase of the hysteresis loops is observed the pore size is reduced [61].
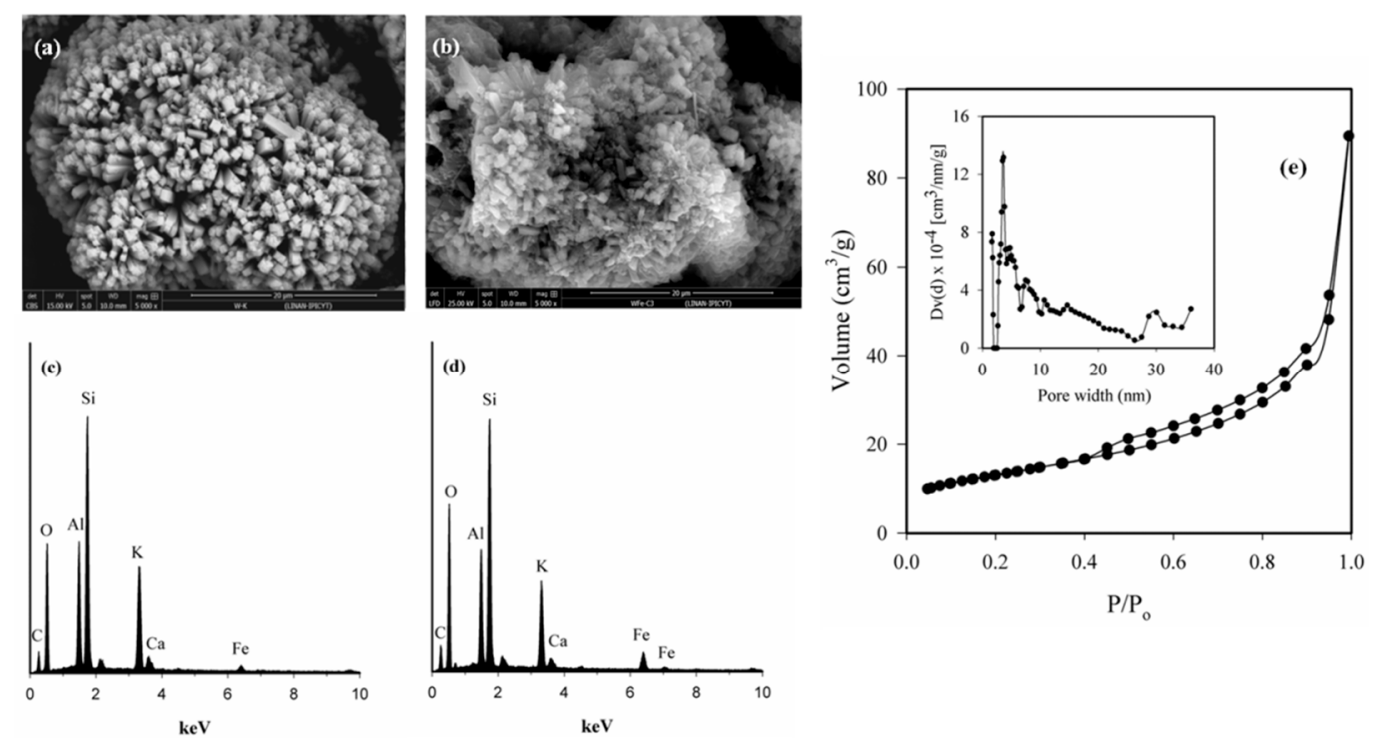

Figure 2. SEM micrographs and EDS spectra of $(\mathbf{a}, \mathbf{c})$ the pristine zeolite and $(\mathbf{b}, \mathbf{d})$ Fe-modified $\mathrm{W}$ zeolite, (e) nitrogen adsorption isotherm and pore size distribution (inset) of the Fe-modified W zeolite.

\subsection{Adsorbent Efficiency as Function of the $\mathrm{pH}$ and the Presence of Coexisting Ions}

The presence of different ions together with arsenic species led to slight variations in the adsorption capacity of the modified zeolite (Figure 3a). Particularly bicarbonate ions did not affect the arsenic adsorption removal. In case of magnesium, sulphate and chloride ions, it was observed that at low concentrations the arsenic adsorption was slightly reduced indicating the competition of ions for the active sites on the Fe-modified W zeolite. However, when the concentration was increased the arsenic removal also increased, achieving the same arsenic adsorption capacity observed when no ions were added. Similar behaviour was reported by Sun et al. they observed that the arsenic adsorption on zero valent iron was increased at high concentrations of sulphate ions [62]. They explained that this increase is due to the acceleration of precipitation of arsenopyrite (FeAsS). According to the literature, the effect of ions on arsenic removal is highly dependent on $\mathrm{pH}$ values, initial concentrations and the ratio between ions and arsenic species [63].

The efficiency of the adsorbent was not drastically affected by the $\mathrm{pH}$ of the solution (Figure $3 \mathrm{~b}$ ). In the $\mathrm{pH}$ interval of 3 to 10 the removal of arsenic was approximately $83 \%$, which was decreased slightly at $\mathrm{pH}$ higher than $8(79 \%)$. This change might be related to the masking of arsenic by iron which impairs its adsorption due to its exposition to high $\mathrm{Fe}-\mathrm{OH}$ environment.

Although several studies report that arsenite removal decreases at highly alkaline $\mathrm{pH}[22,64-66]$. There are some adsorbent materials that showed an increment in the arsenite adsorption capacity as pH increases, such as fly ash [67,68], Mn-natural zeolite [34] and clinoptilolite-supported nanoscale zero-valent iron [40]. This behaviour has been associated to the presence of calcium in the adsorbent where calcium ions tend to form insoluble calcium arsenate. Additionally, the materials mentioned above and the Fe-modified $\mathrm{W}$ zeolite are mainly constituted by alumina and silica, components that confer them a strong alkalinity. This characteristic is reflected in the $\mathrm{pH}$ generated in the system 
(Figure 3b) where the addition of the adsorbent buffering the solution at $\mathrm{pH}$ lowers than 9. Under this condition the predominant specie of arsenite is neutral and enhances the adsorption on the Fe-modified W zeolite. Nevertheless, further studies are required to investigate the mechanism involved in the arsenic adsorption on Fe-modified $\mathrm{W}$ zeolite at alkaline $\mathrm{pH}$.
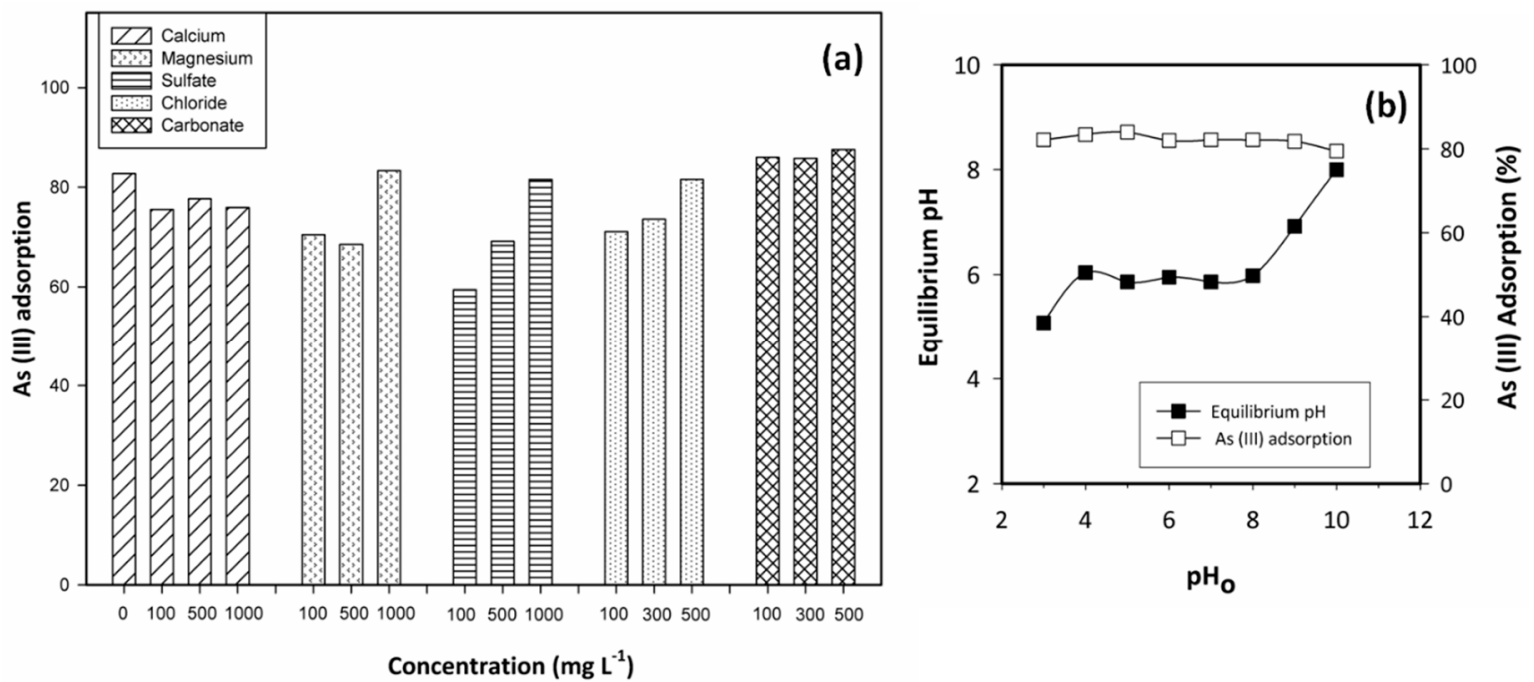

Figure 3. As (III) adsorption on the Fe-modified W zeolite (a) in presence of different ions and (b) at different $\mathrm{pH}$ values.

\subsection{Adsorption Isotherms and Thermodynamic Parameters}

The adsorption isotherms of the two models are shown in Figure $4 \mathrm{a}, \mathrm{b}$. The parameters of both models are summarized in Table 1. In the case of the Langmuir isotherm, the adsorption capacity showed small variations as the temperature increased. According to the Langmuir isotherm the adsorption capacity of the modified zeolite was $0.315 \mathrm{mg} \mathrm{g}^{-1}$. This value is higher than those reported by different low cost adsorbents modified with iron [69-72]. The adsorption coefficient $(b)$ increased when increasing the temperature. A similar behaviour was observed in the DR isotherm where $Q_{\text {max }}$ increased when increasing temperature, reaching the highest value of $15.64 \mathrm{mg} \mathrm{g}^{-1}$ at $35{ }^{\circ} \mathrm{C}$. This fact indicates the endothermic nature of the adsorption process on the Fe-modified $\mathrm{W}$ zeolite. The parameter $E$ associated to the free energy change when one mole of ion is transferred from an infinite solution to the surface of a solid was higher than $8 \mathrm{~kJ} \mathrm{~mol}^{-1}$ for the three evaluated temperatures. This indicates that the adsorption process takes place by ionic exchange [73].

To predict the efficiency of the adsorption process, the dimensionless equilibrium parameter $(r)$ was calculated. Its magnitude was less than 1 and was observed that the value of $r$ decreases as the temperature increases. These results indicated that As (III) removal with Fe-modified W zeolite is a favourable process.

Table 1. Langmuir and DR isotherms for As (III) adsorption on Fe-modified W zeolite.

\begin{tabular}{|c|c|c|c|c|c|c|c|c|}
\hline \multirow[b]{2}{*}{$\begin{array}{c}T \\
(\mathrm{~K})\end{array}$} & \multicolumn{3}{|c|}{ Langmuir. } & \multicolumn{5}{|c|}{ Dubinin Raduskevich } \\
\hline & $\begin{array}{c}q_{m} \\
\left(m g g^{-1}\right)\end{array}$ & $\begin{array}{c}b \\
\left(\mathrm{~L} \mathrm{mg}^{-1}\right)\end{array}$ & $\mathbf{R}^{2}$ & $\begin{array}{c}K \times 10^{3} \\
\left(\mathrm{~mol}^{2} \mathrm{~kJ}^{-2}\right)\end{array}$ & $\begin{array}{c}Q_{\max } \\
\left(\mathrm{mg} \mathrm{g}^{-1}\right)\end{array}$ & $r$ & $\begin{array}{c}E \\
\left(\mathrm{~kJ} \mathrm{~mol}^{-1}\right)\end{array}$ & $\mathbf{R}^{2}$ \\
\hline 288 & 0.315 & 2.230 & 0.9589 & -5.285 & 14.588 & 0.3837 & 9.7266 & 0.9768 \\
\hline 298 & 0.311 & 2.418 & 0.9681 & -5.197 & 14.016 & 0.3648 & 9.8086 & 0.9808 \\
\hline 308 & 0.293 & 2.668 & 0.9847 & -4.583 & 15.646 & 0.3422 & 10.4450 & 0.9874 \\
\hline
\end{tabular}

$\mathrm{R}^{2}$ is the correlation coefficient. 

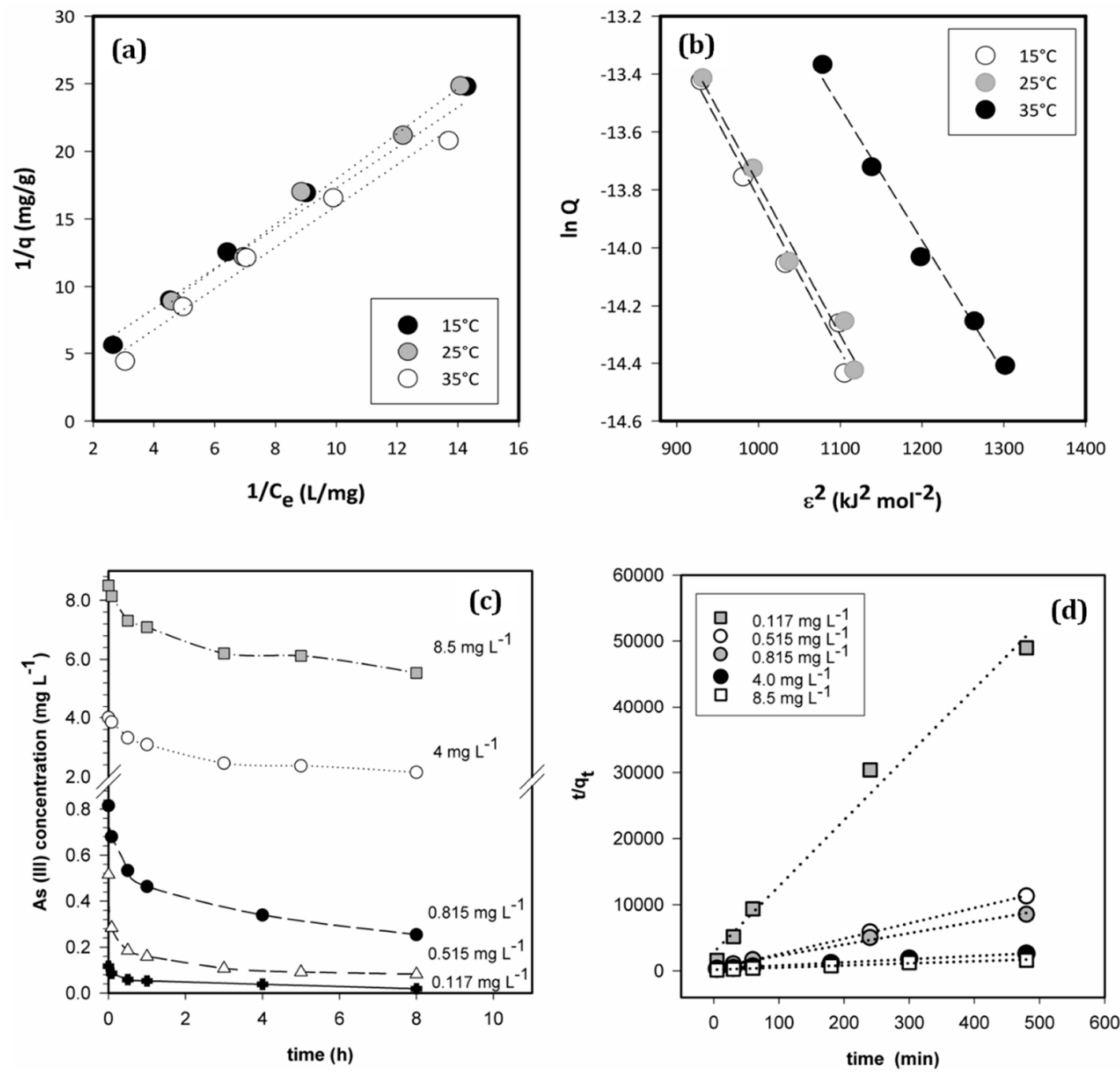

Figure 4. Adsorption isotherms (a) Langmuir and (b) DR, (c) effect of arsenic concentration, (d) kinetic model of pseudo-second order of As (III) adsorption on the Fe-modified W zeolite.

According to the Langmuir model, the adsorption takes place on sites of the same level of energy. Therefore, the enthalpy and the constant $b$ depend on the ion adsorbed on the active site and the temperature. Thus, the Gibbs free energy $\left(\Delta \mathrm{G}^{\circ}\right)$, enthalpy $\left(\Delta \mathrm{H}^{\circ}\right)$ and entropy $\left(\Delta \mathrm{S}^{\circ}\right)$ for As (III) adsorption on the modified zeolite were determined by the Equations (6) and (7). It was observed that $\Delta \mathrm{G}^{\circ}$ decreased as temperature increased. It was of $-31.25 \mathrm{~kJ} \mathrm{~mol}^{-1}$ at $35^{\circ} \mathrm{C}$, while at $25^{\circ} \mathrm{C}$ its value was $-28.79 \mathrm{~kJ} \mathrm{~mol}^{-1}$. The enthalpy was positive $\left(\Delta \mathrm{H}^{\circ}=6.59 \mathrm{~kJ} \mathrm{~mol}^{-1}\right)$ indicating the endothermic nature of the adsorption process. Similar results were obtained by Banerje et al. (2008) in the adsorption of As (III) on granular iron oxide [74]. A positive entropy was obtained $\left(\Delta S^{\circ}=0.1228 \mathrm{~kJ} \mathrm{~mol}^{-1} \mathrm{~K}^{-1}\right)$ which indicates an affinity of the adsorbent for As (III) species [75].

\subsection{Effect of As (III) Concentration}

The initial concentration of As (III) had an important effect on the arsenic removal from the Fe-modified W zeolite. Figure 4c shows that for concentrations lower than $1 \mathrm{mg} \mathrm{L}^{-1}$, the arsenic adsorption was $84 \%$. However, only at the lowest concentration evaluated the residual arsenic concentration was less than the maximum permissible value for total arsenic according to the Mexican norm for drinking water $\left(0.025 \mathrm{mg} \mathrm{L}^{-1}\right)$ [15]. In the case of concentrations of 4 and $8.5 \mathrm{mg} \mathrm{L}^{-1}$, the arsenic removal was only of $46 \%$ and $34 \%$, respectively. 
The pseudo-first and pseudo-second order model allowed to determine the As (III) adsorption rate constant. In Figure 4d, the plots obtained by the kinetic of the pseudo-second order can be observed. The parameters of two kinetic models are presented in Table 2. It is observed that the experimental data fit better with the pseudo-second order model. The adsorption rate constant decreased when the arsenic concentration increased, as well as the adsorption capacity. According to Ho and Mckay, in an adsorption process that fits a pseudo-second-order model, the removal mechanism is mainly by a chemical bond between adsorbate and adsorbent [76]. These findings agree with those obtained by DR isotherms.

Table 2. Kinetic parameters of As (III) adsorption on Fe-modified W zeolite.

\begin{tabular}{|c|c|c|c|c|c|c|}
\hline \multirow{2}{*}{$\begin{array}{c}\text { As (III) } \\
\text { Concentration } \\
\left(\mathrm{mg} \mathrm{L}^{-1}\right)\end{array}$} & \multicolumn{3}{|c|}{ Pseudo First Order } & \multicolumn{3}{|c|}{ Pseudo Second Order } \\
\hline & $\begin{array}{c}k_{1} \\
\left(\min ^{-1}\right)\end{array}$ & $\begin{array}{c}q_{1} \\
\left(\mathrm{mg} \mathrm{L}^{-1}\right)\end{array}$ & $\mathbf{R}^{2}$ & $\left(\mathrm{~g} \mathrm{mg}^{-1} \min ^{-1}\right)$ & $\begin{array}{c}q_{2} \\
\left(\mathrm{mg} \mathrm{L}^{-1}\right)\end{array}$ & $\mathbf{R}^{2}$ \\
\hline 0.117 & 0.005 & 0.0641 & 0.760 & 4.8476 & 0.0100 & 0.986 \\
\hline 0.515 & 0.011 & 0.0206 & 0.845 & 2.5626 & 0.0431 & 0.999 \\
\hline 0.815 & 0.007 & 0.0414 & 0.902 & 0.5145 & 0.0586 & 0.994 \\
\hline 4.0 & 0.007 & 0.1580 & 0.950 & 0.0701 & 0.2082 & 0.997 \\
\hline 8.5 & 0.005 & 0.2386 & 0.902 & 0.0523 & 0.3163 & 0.982 \\
\hline
\end{tabular}

$\mathrm{R}^{2}=$ correlation coefficient.

Additionally, the mass transfer coefficient on As (III) adsorption on the Fe-modified W zeolite was determined. The value of $\beta$ was obtained by the slope from the plot of $\ln \left\{C_{t} / C_{0}-\left[1 /\left(1+\mathrm{M} K_{b q}\right)\right]\right\}$ versus $t$, with $\beta=1.4 \times 10^{-2} \mathrm{~cm} \mathrm{~s}^{-1}\left(\mathrm{R}^{2}=0.9238\right)$. This value was higher than that reported by Singh and Pant for activated alumina and iron-impregnated alumina for As (III) adsorption, $1.9 \times 10^{-3} \mathrm{~cm} \mathrm{~s}^{-1}$ and $3.2 \times 10^{-3} \mathrm{~cm} \mathrm{~s}^{-1}$, respectively [46].

\subsection{Ageing, Desorption and Regeneration of the Fe-Modified W Zeolite}

It is observed that the saturation of Fe-modified $\mathrm{W}$ zeolite depends on the arsenic concentration (Figure 5). For both concentrations evaluated after the third adsorption cycle it was observed releasing of iron (Figure $5 a, b$ ) from the modified zeolite, at higher levels than the permissible values established in the Mexican norms for drinking water. $\left(0.3 \mathrm{mg} \mathrm{L}^{-1}\right)$ [15]. At low concentration $\left(0.2 \mathrm{mg} \mathrm{L}^{-1}\right)$ the arsenic adsorption removal showed a significant decrease from the fifth cycle (Figure $5 c$ ), the reduction was of $70 \%$ in the sixth adsorption cycle furthermore there was no change in the seventh cycle. In case of the arsenic concentration of $1 \mathrm{mg} \mathrm{L}^{-1}$, (Figure 5d) the modified zeolite was reused for three cycles. After the third adsorption cycle the arsenic removal was reduced to $52 \%$, whereas the iron concentration was $0.63 \mathrm{mg} \mathrm{L}^{-1}$.

At the end of the ageing process, the modified zeolite adsorbed $0.125 \mathrm{mg} \mathrm{g}^{-1}$ and $0.20 \mathrm{mg} \mathrm{g}^{-1}$ for concentrations of $0.2 \mathrm{mg} \mathrm{L}^{-1}$ and $1 \mathrm{mg} \mathrm{L}^{-1}$, respectively. The reduction of the As (III) adsorption capacity on the modified zeolite can be related to the saturation of active sites and the loss of affinity to arsenic species as a consequence of iron released from the zeolitic material. According to the decrease in the adsorption capacity of As (III) observed in both systems it was assumed that the adsorbent was sufficiently aged to evaluate the regenerability of the Fe-modified W zeolite.

During the desorption process $22 \%$ of the arsenic was desorbed and no structural changes in the zeolite were observed after the desorption process. The concentration of iron released during this treatment was minimal $\left(0.014 \mathrm{mg} \mathrm{L}^{-1}\right)$. After the desorption process, the Fe-modified $\mathrm{W}$ zeolite was regenerated (Figure $5 \mathrm{~d}$ ), recovering the arsenic adsorption capacity similar to the fresh modified zeolite.

These results allow to conclude that once the active sites of Fe-modified $\mathrm{W}$ zeolite have been saturated with the arsenic species, the aged modified zeolite can be regenerated to recover its original As (III) adsorption capacity. The fact that the Fe-modified zeolite can be used for several cycles of As (III) adsorption enhances the lifetime of this adsorbent and gives it the possibility to be applied in an industrial process. 

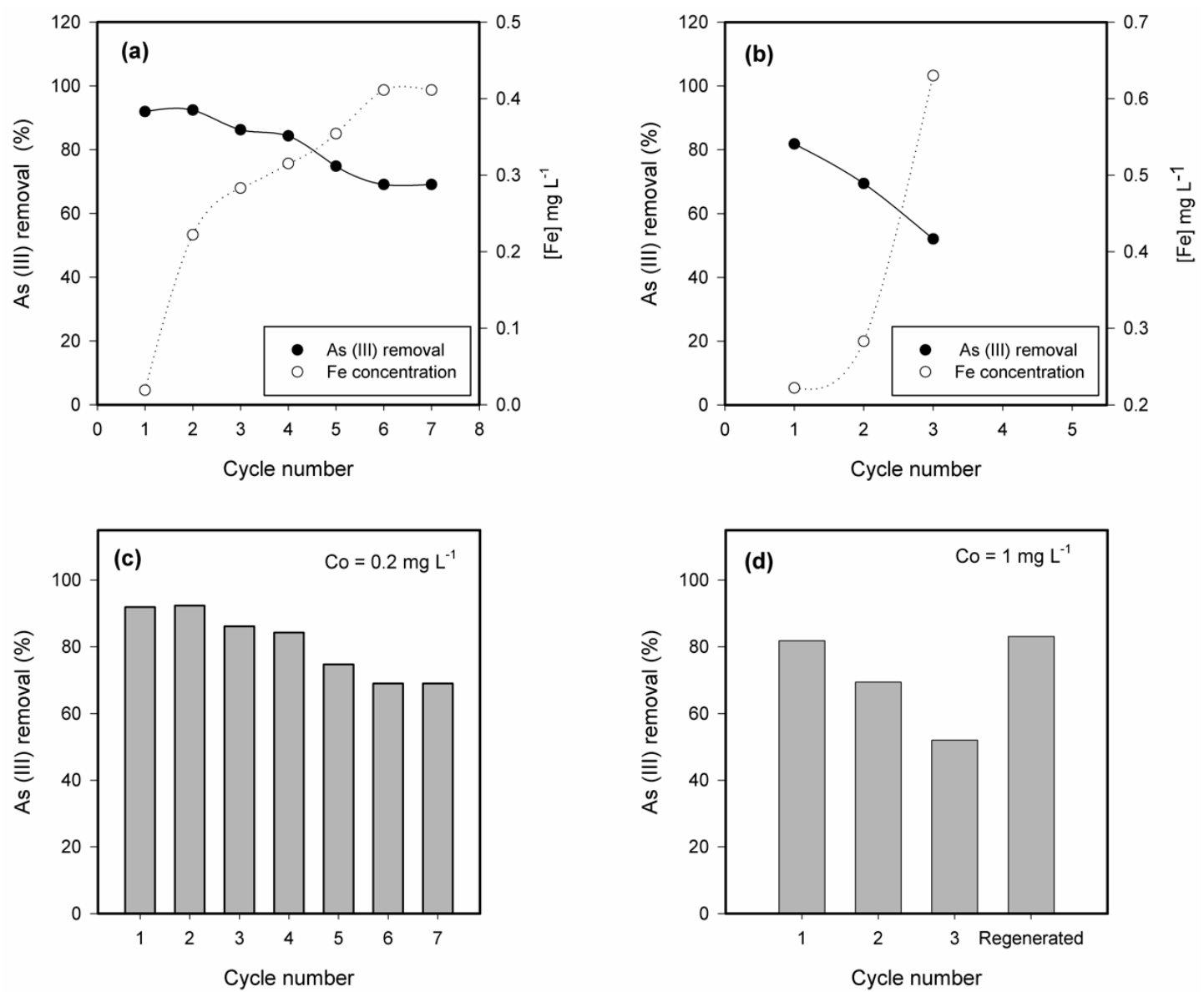

Figure 5. Arsenic removal and iron released at different concentrations (a) $0.2 \mathrm{mg} \mathrm{L}^{-1}$; (b) $1 \mathrm{mg} \mathrm{L}^{-1}$; $(\mathbf{c}, \mathbf{d})$ comparison of arsenic adsorption capacity of the pristine, reused and regenerated Fe-modified W zeolite.

\subsection{Eco-Scale Applied to W Zeolite Synthesis from Fly Ash}

The results obtained of E-factor, cost and Eco-scale for the synthesis of W zeolite from fly ash and raw materials of reagent grade are presented in Table 3. The E- factor is related to waste generation by the process [53]. It can be observed that the value of E-factor for synthesis procedure was $10.1 \mathrm{Kg}$ of waste per kilogram of $\mathrm{W}$ zeolite synthesized from fly ash. In case of the $\mathrm{W}$ zeolite synthesized from precursors of analytical grade the E-factor was higher (16.03 Kg of wastes $/ \mathrm{Kg} \mathrm{W}$ zeolite).

In the direct transformation of the MFA in W zeolite, the zeolite is separated from the mother liquor by filtering, the concentration of $\mathrm{KOH}$ could be adjusted and it could be used again in a new lot of $\mathrm{W}$ zeolite. If liquor mother is recycled to the process, a E-Factor near to zero would be obtained and the process to obtain the $\mathrm{W}$ zeolite would be considered as a green process.

The approximated cost of $\mathrm{W}$ zeolite was calculated considering only the prices of raw materials used to produce it. The cost of W zeolite synthesized from fly ash was estimated in $0.02 \mathrm{USD} / \mathrm{g}$ while the $\mathrm{W}$ zeolite obtained using materials of analytical grade was 5 times more expensive $(0.11 \mathrm{USD} / \mathrm{g}$ of zeolite). According with the Eco-Scale principles and the estimated costs, the W zeolite produced from fly ash is inexpensive because the cost is lower than 10 USD per $10 \mathrm{mmol}$ of $\mathrm{W}$ zeolite. Calculated molecular weight of W zeolite is $4012.57 \mathrm{~g} / \mathrm{mol}$. These findings allow to infer that the $\mathrm{W}$ zeolite synthesis from fly ash is economically feasible. 
Table 3. E-Factor, cost and Eco-Scale applied to synthesis of W zeolite comparing the type of precursors.

(A) E-Factor; (B) Cost; (C) Eco-Scale.

\begin{tabular}{|c|c|c|c|c|c|c|c|}
\hline \multicolumn{4}{|c|}{ W Zeolite Synthesis (from Fly Ash) } & \multicolumn{4}{|c|}{ W Zeolite Synthesis (from Analytical Reagents) } \\
\hline Reagent & $\begin{array}{l}\text { Amount } \\
(\mathrm{g})\end{array}$ & $\underset{(m L)}{\text { Amount }}$ & $\begin{array}{c}\text { Total } \\
\text { Mass (g) }\end{array}$ & Reagent & $\begin{array}{c}\text { Amount } \\
\text { (g) }\end{array}$ & $\underset{(m L)}{\text { Amount }}$ & $\begin{array}{c}\text { Total } \\
\text { Mass (g) }\end{array}$ \\
\hline Fly ash & 160 & & 160 & Ludox & & 232.68 & 302.48 \\
\hline $\mathrm{KOH}$ & 53.20 & & 53.20 & $\mathrm{Al}_{2} \mathrm{Na}_{2} \mathrm{O}_{4}$ & 41.45 & & 41.45 \\
\hline \multirow[t]{2}{*}{ Water ${ }^{1}$} & & 1980 & 1980 & $\mathrm{KOH}$ & 154.99 & & 154.99 \\
\hline & & & & Water ${ }^{1}$ & & 2700 & 2700 \\
\hline Total wastes & & & 2193.20 & Total wastes & & & 3198.93 \\
\hline W zeolite $(\mathrm{g})$ & & & 197.5 & W zeolite (g) & & & 187.87 \\
\hline E-Factor & $(2193.20$ & $197.5) / 19$ & $5=10.10$ & E-Factor & (3198.93 & $187.87) / 18$ & $7=16.03$ \\
\hline
\end{tabular}

(A)

${ }^{1}$ The water includes the water used for synthesis and for washing.

\begin{tabular}{|c|c|c|c|c|c|c|c|c|c|}
\hline \multicolumn{5}{|c|}{ W Zeolite Synthesis (from Fly Ash) } & \multicolumn{5}{|c|}{ W Zeolite Synthesis (from Analytical Reagents) } \\
\hline Reagent & $\begin{array}{l}\text { Amount } \\
\text { (g) }\end{array}$ & $\begin{array}{l}\text { Amount } \\
(\mathrm{mL})\end{array}$ & $\begin{array}{c}\text { Price } \\
\text { (USD/g) }\end{array}$ & $\begin{array}{l}\text { Total } \\
\text { (USD/g) }\end{array}$ & Reagent & $\begin{array}{l}\text { Amount } \\
\text { (g) }\end{array}$ & $\begin{array}{l}\text { Amount } \\
(\mathrm{mL})\end{array}$ & $\begin{array}{c}\text { Price } \\
\text { (USD/g) }\end{array}$ & $\begin{array}{c}\text { Total } \\
\text { (USD/g) }\end{array}$ \\
\hline Fly ash & 160 & & 0 & 0 & Ludox & 302.48 & 232.68 & 0.03529 & 10.6752 \\
\hline $\mathrm{KOH}$ & 53.20 & & 0.044 & 2.3408 & $\mathrm{Al}_{2} \mathrm{Na}_{2} \mathrm{O}_{4}$ & 41.45 & & 0.0463 & 1.9191 \\
\hline \multirow[t]{2}{*}{ Water } & & 1980 & 0.00082 & 1.6424 & $\mathrm{KOH}$ & 154.99 & & 0.044 & 6.8195 \\
\hline & & & & & Water & & 2700 & 0.00082 & 2.214 \\
\hline Total cost ${ }^{2}$ & & & & 3.9832 & Total cost & & & & 21.6278 \\
\hline \multirow{2}{*}{\multicolumn{4}{|c|}{$\begin{array}{l}\text { W zeolite }(\mathrm{g}) \\
\text { Cost W zeolite (USD/g) }\end{array}$}} & 197.5 & \multicolumn{3}{|c|}{ W zeolite (g) } & & 187.87 \\
\hline & & & & 0.0201 & \multicolumn{3}{|c|}{ Cost W zeolite (USD/g) } & & 0.1151 \\
\hline
\end{tabular}

(B)

2 The cost only includes the raw materials.

\begin{tabular}{|c|c|c|c|c|c|}
\hline \multicolumn{3}{|c|}{ W Zeolite Synthesis (from Fly Ash) } & \multicolumn{3}{|c|}{ W Zeolite Synthesis (from Analytical Reagents) } \\
\hline Parameter & & $\begin{array}{c}\text { Penalty } \\
\text { Points }\end{array}$ & Parameter & & $\begin{array}{c}\text { Penalty } \\
\text { Points }\end{array}$ \\
\hline Price to obtain $10 \mathrm{mmol}$ & Inexpensive (<USD10) & 0 & Price to obtain $10 \mathrm{mmol}$ & Inexpensive (<USD10) & 0 \\
\hline \multirow{2}{*}{ Safety } & $\mathrm{KOH}$ & 3 & & $\mathrm{KOH}$ & 3 \\
\hline & Fly ash & 1 & & $\mathrm{Al}_{2} \mathrm{Na}_{2} \mathrm{O}_{4}$ & 3 \\
\hline$W \& P$ & Simple filtration & 0 & W\&P & Simple filtration & 0 \\
\hline Total penalty points (TPP) & & 10 & Total penalty points (TTP) & & 12 \\
\hline Eco-Scale & $(100-\mathrm{TPP})$ & 90 & Eco-Scale & $(100-\mathrm{TPP})$ & 88 \\
\hline
\end{tabular}

(C) ${ }^{3}$ The yield was calculated respect to (silica + alumina) content of the precursors; W\&P = workup and purification; $\mathrm{PE}=$ Pressure equipment.

The principles of Eco-Scale consider that transformation of substrate by a chemical reaction into a desired compound is taking place by an inexpensive reagents at low temperatures, in a $100 \%$ yield and with a minimal impact for the environment [51]. The yield (calculated with respect to silica+alumina content of the precursors) of the $\mathrm{W}$ zeolite synthesized from fly ash was $153.4 \%$ while the $\mathrm{W}$ zeolite obtained from reagent materials was of $128 \%$. These results allow to infer that the $\mathrm{W}$ zeolite synthesis from fly ash is economically feasible and it led to higher yields. The magnitude of the Eco-Scale determines how much green the process is. According with the results for the synthesis of $\mathrm{W}$ zeolite the Eco-scale was higher than $75 \%$ indicating that this method is an excellent green process.

\section{Conclusions}

The W zeolite obtained by a direct zeolitization of fly ash was modified by ionic exchange with an iron salt and the As (III) adsorption capacity of the resultant material was evaluated. According to 
the thermodynamic study, the adsorption of As (III) by a Fe-modified W zeolite is a spontaneous, feasible and endothermic process. The kinetic study indicates that the adsorption process takes place by chemical bond.

The Fe-modified $\mathrm{W}$ zeolite showed to adsorb As (III) in a broad $\mathrm{pH}$ range even in the presence of coexistent ions. As well, it was demonstrated that the As (III) anionic species are desorbed at alkaline conditions and that the aged Fe-modified $\mathrm{W}$ zeolite could be easily regenerated by giving it the possibility to extend its useful lifetime.

The Fe-modified W zeolite ageing process depends on the As (III) concentration of the model water solution. At $0.2 \mathrm{mg} \mathrm{L}^{-1}$ the arsenic removal exhibited an important decrease in the fifth aging cycle. Considering that underground water has an As (III) concentration lower than $0.2 \mathrm{mg} \mathrm{L}^{-1}$ (in "La Laguna" region), it is expected that the Fe-modified W zeolite would be useful to reduce the concentration of As (III) in water at permissible levels and that it could be reused more than five times.

The $\mathrm{W}$ zeolite is produced from an industrial by-product with no commercial value in a one-pot zeolitization process that generates small amount of waste per $\mathrm{kg}$ of zeolite, which makes it a low-cost-production product, increasing its Eco-scale value. Additionally, the Fe-modified W zeolite presents a high adsorption capacity of As (III) and it is regenerated several times increasing its lifetime.

In conclusion, the Fe-modified $\mathrm{W}$ zeolite is viable and potentially useful in the formulation of filtering materials to treat underground water with high concentration of As (III). Nevertheless, additional studies should be conducted to increase the number of activation-aging-regeneration cycles of the Fe-modified W zeolite that leads to an extended lifetime of the final As (III) adsorbent. In addition, the final adsorbent should meet the physicochemical properties required to be packed in a filtering system to treat groundwater at industrial level.

Author Contributions: Conceptualization, P.G.-M.; Formal analysis, B.R.-C. and R.R.-T.; Funding acquisition, P.G.-M.; Investigation, A.M.-R.; Resources, J.I.M.-M. and K.Y.G.-V.; Validation, B.R.-C. and R.R.-T.; Writing —original draft, A.M.-R.; Writing—review \& editing, J.I.M.-M. and K.Y.G.-V.

Funding: This research was funded by SENER-CONACyT-Hidrocarburos and Develop Scientific Projects to Address National Problems Mexican funds, Project numbers 144453 and 247660, respectively.

Acknowledgments: The authors acknowledge M. S. García-Guillermo for her contribution to this work and E. Medina (Eng.) for his help in the English edition.

Conflicts of Interest: The authors declare no conflict of interest. The funders had no role in the design of the study; in the collection, analyses or interpretation of data; in the writing of the manuscript or in the decision to publish the results.

\section{References}

1. Huang, L.; Wu, H.; Kuijp, T.J. The health effects of exposure to arsenic-contaminated drinking water: A review by global geographical distribution. Int. J. Environ. Health Res. 2015, 25, 432-452. [CrossRef] [PubMed]

2. Bienert, G.P.; Tamás, M.J. Molecular mechanisms of metalloid transport, toxicity and tolerance. Front. Cell Dev. Biol. 2018, 6, 99. [CrossRef] [PubMed]

3. Laine, J.E.; Ilievski, V.; Richardson, D.B.; Herring, A.H.; Styblo, M.; Rubio-Andrade, M.; García-Vargas, G.; Gamble, M.V.; Fry, R.C. Maternal one carbon metabolism and arsenic methylation in a pregnancy cohort in Mexico. J. Expo. Sci. Environ. Epidemiol. 2018, 28, 505-514. [CrossRef] [PubMed]

4. González-Horta, C.; Ballinas-Casarrubias, L.; Sánchez-Ramírez, B.; Ishida, M.C.; Barrera-Hernández, A.; Gutiérrez-Torres, D.; Zacarias, O.L.; Saunders, R.S.; Drobná, Z.; Mendez, M.A.; et al. A Concurrent exposure to arsenic and fluoride from drinking water in Chihuahua, Mexico. Int. J. Environ. Res. Public Health 2015, 12, 4587-4601. [CrossRef]

5. Nelson-Mora, J.; Escobar, M.L.; Rodriguez-Duran, L.; Massieu, L.; Montiel, T.; Rodríguez, V.M.; Hernandez-Mercado, K.; Gonsebatt, M.E. Gestational exposure to inorganic arsenic (iAs3+) alters glutamate disposition in the mouse hippocampus and ionotropic glutamate receptor expression leading to memory impairment. Arch. Toxicol. 2018, 92, 1037-1048. [CrossRef] [PubMed] 
6. Del Razo, L.M.; García-Vargas, G.G.; Valenzuela, O.L.; Hernández Castellanos, E.; Sánchez-Peña, L.C.; Currier, J.M.; Drobnaa, Z.; Loomis, D.; Stýblo, M. Exposure to arsenic in drinking water is associated with increased prevalence of diabetes: A cross-sectional study in the Zimapán and Lagunera regions in Mexico. Environ. Health 2013, 10, 73. [CrossRef] [PubMed]

7. Monrad, M.; ErsbØll, A.K.; SØrense, M.; Baastrup, R.; Hansen, B.; Gammelmark, A.; Tjonneland, A.; Overvad, K.; Raaschou-Nielsen, O. Low-level arsenic in drinking water and risk of incident myocardial infarction: A cohort study. Environ. Res. 2017, 154, 318-324. [CrossRef] [PubMed]

8. Susko, M.L.; Bloom, M.S.; Neamtiu, I.A.; Appleton, A.A.; Surdu, S.; Pop, C.; Fitzgerald, E.F.; Anastasiu, D.; Gurzau, E.S. Low-level arsenic exposure via drinking water consumption and female fecundity-A preliminary investigation. Environ. Res. 2017, 154, 120-125. [CrossRef]

9. Cheng, Y.Y.; Huang, N.C.; Chang, Y.T.; Sung, J.M.; Shen, K.H.; Tsai, C.C.; Guo, H.R. Associations between arsenic in drinking water and the progression of chronic kidney disease: A nationwide study in Taiwan. J. Hazard. Mater. 2017, 321, 432-439. [CrossRef]

10. Hussain, A.; Raveendran, V.A.; Kundu, S.; Samanta, T.; Shunmugam, R.; Pal, D.; Sarma, J.D. Mechanisms of Arsenic-Induced Toxicity with Special Emphasis on Arsenic-Binding Proteins. In Arsenic-Analytical and Toxicological Studies, 1st ed.; Stoytcheva, M., Zlatev, R., Eds.; IntechOpen: London, UK, 2018; Chapter 5; pp. 57-80, ISBN 978-1-78923-517-3.

11. Aguilar-Muñiz, A.U.; Valdes-Perezgasga, F.; Garcia-Vargas, G.G. Seasonal effects in arsenic levels in drinking water in the Lagunera region. J. Phys. Conf. Ser. 2013, 421, 012017. [CrossRef]

12. Ortega-Guerrero, A. Evaporative concentration of arsenic in groundwater: Health and environmental implications, La Laguna Region, Mexico. Environ. Geochem. Health 2017, 39, 987-1003. [CrossRef] [PubMed]

13. Camacho, M.; Gutierrez, M.; Alarcon-Herrera, M.T.; Villalba, M.L.; Deng, S. Occurrence and treatment of arsenic in groundwater and soil in northern Mexico and southwestern USA. Chemosphere 2011, 83, 211-225. [CrossRef] [PubMed]

14. Ruiz-Huerta, E.A.; de la Garza Varela, A.; Gomez-Bernal, J.M.; Castillo, F.; Avalos-Borja, M.; SenGupta, B.; Martínez-Villegas, N. Arsenic contamination in irrigation water, agricultural soil and maize crop from an abandoned smelter site in Matehuala, Mexico. J. Hazard. Mater. 2017, 339, 330-339. [CrossRef] [PubMed]

15. Modificacion a la Norma Oficial Mexicana NOM-127-SSA1-1994. Available online: https:/ / www.gob.mx/cms/uploads/attachment/file/110520/MODIFICACION_A_LA_NORMA_ NOM_127_SSA1_1994_22_NOVIEMBRE_2000.pdf (accessed on 3 September 2018).

16. García-Rico, L.; Meza-Figueroa, D.; Gandolfi, A.J.; Ibañez del Rivero, C.; Martínez-Cinco, M.A.; Meza-Montenegro, M.M. Health Risk Assessment and Urinary Excretion of Children Exposed to Arsenic through Drinking Water and Soils in Sonora, Mexico. Biol. Trace Elem. Res. 2018, 187, 9-21. [CrossRef] [PubMed]

17. Cohen, S.M.; Arnold, L.L.; Beck, B.D.; Lewis, A.S.; Eldan, M. Evaluation of the carcinogenicity of inorganic arsenic. Crit. Rev. Toxicol. 2013, 43, 711-752. [CrossRef] [PubMed]

18. Mondal, P.; Balomajumder, C.; Mohanty, B. A laboratory study for the treatment of arsenic, iron, and manganese bearing ground water using Fe3+ impregnated activated carbon: Effects of shaking time, $\mathrm{pH}$ and temperature. J. Hazard. Mater. 2007, 144, 420-426. [CrossRef] [PubMed]

19. Giles, D.E.; Mohapatra, M.; Issa, T.B.; Anand, S.; Singh, P. Iron and aluminium based adsorption strategies for removing arsenic from water. J. Environ. Manag. 2011, 92, 3011-3022. [CrossRef] [PubMed]

20. DeMarco, M.J.; SenGupta, A.K.; Greenleaf, J.E. Arsenic removal using a polymeric/inorganic hybrid sorbent. Water Res. 2003, 37, 164-176. [CrossRef]

21. Jaya, J.A.; Blute, N.K.; Hemond, H.F.; Durant, J.L. Arsenic-sulfides confound anion exchange resin speciation of aqueous arsenic. Water Res. 2004, 38, 1155-1158. [CrossRef]

22. Nicomel, N.R.; Leus, K.; Folens, K.; Van Der Voort, P.; Laing, G.D. Technologies for Arsenic Removal fromWater: Current Status and Future Perspectives. Int. J. Environ. Res. Public Health 2016, 13, 62. [CrossRef]

23. Mendoza, R.M.O.; Kan, C.C.; Chuang, S.S.; Pingul-Ong, S.M.B.; Dalida, M.L.P.; Wan, M.W. Feasibility studies on arsenic removal from aqueous solutions by electrodialysis. J. Environ. Sci. Health A 2014, 49, 545-554. [CrossRef] [PubMed]

24. Neppolian, B.; Celik, E.; Choi, H. Photochemical Oxidation of Arsenic(III) to Arsenic(V) using Peroxydisulfate Ions as an Oxidizing Agent. Environ. Sci. Technol. 2008, 42, 6179-6184. [CrossRef] [PubMed] 
25. Kasiuliene, A.; Carabante, I.; Bhattacharya, P.; Caporale, A.G.; Adamo, P.; Kumpiene, J. Removal of metal(oid)s from contaminated water using iron-coated peat sorbent. Chemosphere 2018, 198, 290-296. [CrossRef] [PubMed]

26. Gallios, G.P.; Tolkou, A.K.; Katsoyiannis, I.O.; Stefusova, K.; Vaclavikova, M.; Deliyanni, E.A. Adsorption of Arsenate by Nano Scaled Activated Carbon Modified by Iron and Manganese Oxides. Sustainability 2017, 9 , 1684. [CrossRef]

27. Mahmood, T.; Aslam, M.; Naeem, A.; Siddique, T.; Din, S.U. Adsorption of As(III) from aqueous solution onto iron impregnated used tea activated carbon: Equilibrium, kinetic and thermodynamic study. J. Chil. Chem. Soc. 2018, 63, 3855-3866. [CrossRef]

28. Montero, J.I.Z.; Monteiro, A.S.C.; Gontijo, E.S.J.; Bueno, C.C.; de Moraes, M.A.; Rosa, A.H. High efficiency removal of As(III) from waters using a new and friendly adsorbent based on sugarcane bagasse and corncob husk Fe-coated biochars. Ecotoxicol. Environ. Saf. 2018, 162, 616-624. [CrossRef]

29. Katsoyiannis, I.A.; Tzollas, N.M.; Tolkou, A.K.; Mitrakas, M.; Ernst, M.; Zouboulis, A.I. Use of Novel Composite Coagulants for Arsenic Removal from Waters-Experimental Insight for the Application of Polyferric Sulfate (PFS). Sustainability 2017, 9, 590. [CrossRef]

30. Figueiredo, H.; Quintelas, C. Tailored zeolites for the removal of metal oxyanions: Overcoming intrinsic limitations of zeolites. J. Hazard. Mater. 2014, 274, 287-299. [CrossRef]

31. Wang, S.; Peng, Y. Natural zeolites as effective adsorbents in water and wastewater treatment. Chem. Eng. J. 2010, 156, 11-24. [CrossRef]

32. Šiljeg, M.; Foglar, L.; Gudelj, I. The removal of arsenic from water with natural and modified clinoptilolite. Chem. Ecol. 2012, 28, 75-87. [CrossRef]

33. Simsek, E.B.; Özdemir, E.; Beker, U. Process optimization for arsenic adsorption onto natural zeolite incorporating metal oxides by response surface methodology. Water Air Soil Pollut. 2013, 224, 1614. [CrossRef]

34. Mejia-Zamudio, F.; Valenzuela-Garcia, J.; Gomez-Alvarez, A.; Meza-Figueroa, D.; Ela, W.P. Adsorption of arsenic on pre-treated zeolite at different $\mathrm{pH}$ levels. J. Chem. Speciat. Bioavailab. 2013, 25, 280-284. [CrossRef]

35. Payne, K.B.; Abdel-Fattah, T.M. Adsorption of arsenate and arsenite by iron-treated activated carbon and zeolites: Effects of $\mathrm{pH}$, temperature, and ionic strength. J. Environ. Sci. Health A 2005, 40, 723-749. [CrossRef]

36. Shukla, E.A.; Johan, E.; Henmi, T.; Matsue, N. Arsenate adsorption on iron modified artificial zeolite made from coal fly ash. Procedia Environ. Sci. 2013, 17, 279-284. [CrossRef]

37. Johan, E.; Shukla, E.A.; Matsue, N.; Henmi, T. Fe-treated artificial zeolite as an adsorbent for anionic and cationic pollutants. Procedia Environ. Sci. 2013, 17, 285-290. [CrossRef]

38. Kong, S.; Wang, Y.; Zhan, H.; Yuan, S.; Yu, M.; Liu, M. Adsorption/oxidation of arsenic in groundwater by nanoscale Fe-Mn binary oxides loaded on zeolite. Water Environ. Res. 2014, 86, 147-155. [CrossRef] [PubMed]

39. Macedo-Miranda, M.G.; Olguin, M.T. Arsenic sorption by modified clinoptilolite-heulandite rich tuffs. J. Incl. Phenom. Macrocycl. Chem. 2007, 59, 131-142. [CrossRef]

40. Li, Z.; Wang, L.; Meng, J.; Liu, X.; Xu, J.; Wang, F.; Brookes, P. Zeolite-supported nanoscale zero-valent iron: New findings on simultaneous adsorption of $\mathrm{Cd}(\mathrm{II}), \mathrm{Pb}(\mathrm{II})$, and $\mathrm{As}(\mathrm{III})$ in aqueous solution and soil. J. Hazard. Mater. 2018, 344, 1-11. [CrossRef]

41. Medina, A.; Gamero, P.; Querol, X.; Moreno, N.; De León, B.; Almanza, M.; Vargas, G.; Izquierdo, M.; Font, O. Fly ash from a Mexican mineral coal I: Mineralogical and chemical characterization. J. Hazard. Mater. 2010, 181, 82-90. [CrossRef]

42. Medina, A.; Gamero, P.; Almanza, J.M.; Vargas, A.; Montoya, A.; Vargas, G.; Izquierdo, M. Fly ash from a Mexican mineral coal II. Source of w zeolite and its effectiveness in arsenic (V.) adsorption. J. Hazard. Mater. 2010, 181, 91-104. [CrossRef]

43. Jimenez-Cedillo, M.J.; Olguin, M.T.; Fall, C. Adsorption kinetic of arsenates as water pollutant on iron, manganese and iron-manganese-modified clinoptilolite-rich tuffs. J. Hazard. Mater. 2009, 163, 939-945. [CrossRef] [PubMed]

44. Langmuir, D. Aqueous Environmental Geochemistry, 1st ed.; Prentice Hall: Upper Saddle River, NJ, USA, 1997; pp. 360-364, ISBN 0-02-367412-1.

45. Ayben, K.; Binay, B. Thermodynamic and kinetic investigations of uranium adsorption on amberlite IR-118H resin. Appl. Radiat. Isot. 2003, 58, 155-160. [CrossRef] 
46. Singh, T.S.; Pant, K.K. Equilibrium, kinetics and thermodynamic studies for adsorption of As (III) on activated alumina. Sep. Purif. Technol. 2004, 36, 139-147. [CrossRef]

47. Di Natale, F.; Erto, A.; Lancia, A.; Musmarra, D. Experimental and modelling analysis of As (V) ions adsorption on granular activated carbon. Water Res. 2008, 42, 2007-2016. [CrossRef] [PubMed]

48. Lagergren, S. About the theory of so-called adsorption of soluble substances. Kungliga Svenska Vetenskapsakademiens Handlingar 1898, 24, 1-39.

49. Ho, Y.S.; McKay, G.A. A comparison of chemisorption kinetic models applied to pollutant removal on various sorbents. Process Saf. Environ. Prot. 1998, 76, 332-340. [CrossRef]

50. McKay, G.; Otterburn, M.S.; Sweeney, A.G. Surface mass transfer processes during color removal from effluent using silica. Water Res. 1981, 15, 327-331. [CrossRef]

51. Van Aken, K.; Strekowski, L.; Patiny, L. EcoScale, a semi-quantitative tool to select an organic preparation based on economical and ecological parameters. Beilstein J. Org. Chem. 2006, 2, 3. [CrossRef]

52. Pini, M.; Rosa, R.; Neri, P.; Bondioli, F.; Ferrari, A.M. Environmental assessment of a bottom-up hydrolytic synthesis of $\mathrm{TiO}_{2}$ nanoparticles. Green Chem. 2015, 17, 518-531. [CrossRef]

53. Gałuszka, A.; Konieczka, P.; Migaszewski, Z.M.; Namiésnik, J. Analytical Eco-Scale for assessing the greenness of analytical procedures. TrAC Trends Anal. Chem. 2012, 37, 61-72. [CrossRef]

54. Knops-Gerrits, P.P.; De Vos, D.E.; Feijen, E.J.P.; Jacobs, P.A. Raman spectroscopy on zeolites. Microporous Mater. 1997, 8, 3-17. [CrossRef]

55. Huang, Y.; Paroli, R.M.; Delgado, A.H.; Richardson, T.A. An FT-Raman study of solid-state ion exchange in zeolites. Spectrochim. Acta Part A 1998, 54, 1347-1354. [CrossRef]

56. Seo, Y.H.; Prasentyanto, E.A.; Jiang, N.; Oh, S.M.; Park, S.E. Catalytic dehydration of methanol over synthetic zeolite W. Microporous Mesoporous Mater. 2010, 128, 108-114. [CrossRef]

57. Yu, Y.; Xiong, G.; Li, C.; Xiao, F.S. Characterization of iron atoms in the framework of MFI-type zeolites by UV resonance Raman spectroscopy. J. Catal. 2000, 194, 487-490. [CrossRef]

58. Kim, S.H.; Kim, S.D.; Kim, Y.C.; Kim, C.-S.; Hong, S.B. Synthesis and characterization of Ga-substituted MER-type zeolites. Microporous Mesoporous Mater. 2001, 42, 121-129. [CrossRef]

59. Houlleberghs, M.; Breynaerta, E.; Asselmana, K.; Vaneeckhautea, E.; Radhakrishnana, S.; Anderson, M.W.; Taulellea, F.; Haouas, M.; Martens, J.A.; Kirschhock, C.E.A. Evolution of the crystal growth mechanism of zeolite W (MER) with temperature. Microporous Mesoporous Mater. 2019, 274, 379-384. [CrossRef]

60. Rouquerol, J.; Rouquerol, F.; Sing, K. Adsorption by Powders and Porous Solid, Principles, Methodology and Applications, 1st ed.; Academic Press: London, UK, 1999; pp. 439-442, ISBN 978-0-12-598920-6.

61. Lowell, S.; Shields, J.E.; Thomas, M.A.; Thommes, M. Characterization of Porous Solids and Powders: Surface Area, Pore Size and Density, 1st ed.; Kluwer Academic Publishers: Dordrecht, The Netherlands, 2004; pp. 26-55, ISBN 1-4020-2303-0.

62. Sun, H.; Wang, L.; Zhang, R.; Sui, J.; Xu, G. Treatment of groundwater polluted by arsenic compounds by zero valent iron. J. Hazard. Mater. 2006, 129, 297-303. [CrossRef]

63. Biterna, M.; Arditsoglou, A.; Tsikouras, E.; Voutsa, D. Arsenate removal by zero valent iron: Batch and column tests. J. Hazard. Mater. 2007, 149, 548-552. [CrossRef]

64. Sarntanayoot, P.; Fuangswasdi, S.; Imyim, A. Iron nanoparticle-modified water treatment residues for adsorption of $\mathrm{As}(\mathrm{III})$ and $\mathrm{As}(\mathrm{V})$ and their cement-based solidification/stabilization. Int. J. Environ. Sci. Technol. 2018. [CrossRef]

65. Wei, Z.; Liang, K.; Wu, Y.; Zou, Y.; Zuo, J.; Cortés Arriagada, D.; Pan, Z.; Hu, G. The effect of pH on the adsorption of arsenic(III) and arsenic(V) at the TiO2 anatase [ [ 1011$]$ surface. J. Colloid Interface Sci. 2016, 462, 252-259. [CrossRef]

66. Feng, Q.; Zhang, Z.; Ma, Y.; He, X.; Zhao, Y.; Chai, Z. Adsorption and desorption characteristics of arsenic onto ceria nanoparticles. Nanoscale Res. Lett. 2012, 7, 84. [CrossRef] [PubMed]

67. Bertocchi, A.; Ghiani, M.; Peretti, R.; Zucca, A. Red mud and fly ash for remediation of mine sites contaminated with As, Cd, Cu, Pb and Zn. J. Hazard. Mater. 2006, 134, 112-119. [CrossRef] [PubMed]

68. Polowczyk, I.; Bastrzyk, A.; Ulatowska, J.; Szczałba, E.; Koźlecki, T.; Sadowski, Z. Influence of pH on arsenic(III) removal by fly ash. Sep. Sci. Technol. 2016, 51, 2612-2619. [CrossRef]

69. Li, Z.; Beachner, R.; McManama, Z.; Hanlie, H.H. Sorption of arsenic by surfactant-modified zeolite and kaolinite. Microporous Mesoporous Mater. 2007, 105, 291-297. [CrossRef] 
70. Das, B.; Devi, R.R.; Umlong, I.M.; Borah, K.; Banerjee, S.; Talukdar, A.K. Arsenic (III) adsorption on iron acetate coated activated alumina: Thermodynamic, kinetics and equilibrium approach. J. Environ. Health Sci. Eng. 2013, 11, 42. [CrossRef] [PubMed]

71. Devi, R.R.; Umlong, I.O.; Das, B.; Borah, K.; Thakur, A.J.; Raul, P.K.; Banerjee, S.; Singh, L. Removal of iron and arsenic (III) from drinking water using iron oxide-coated sand and limestone. Appl. Water Sci. 2014, 4, 175-182. [CrossRef]

72. Ananta, S.; Banerjee, S.; Vijay, V. Adsorption Isotherm, Thermodynamic and kinetic study of arsenic (III) on iron oxide coated granular activated charcoal. Int. Res. J. Environ. Sci. 2015, 4, 64-77.

73. Suzuki, T.M.; Bomani, J.O.; Matsunaga, H.; Yokoyama, T. Preparation of porous resin loaded with crystalline hydrous zirconium oxide and its application to the removal of arsenic. React. Funct. Polym. 2000, 43, 165-172. [CrossRef]

74. Banerjee, K.; Amy, G.L.; Prevost, M.; Nour, S.; Jekel, M.; Gallagher, P.M.; Blumenschein, C.D. Kinetic and thermodynamic aspects of adsorption of arsenic onto granular ferric hydroxide (GFH). Water Res. 2008, 42, 3371-3378. [CrossRef]

75. Kuriakose, S.; Singh, T.S.; Pant, K.K. Adsorption of As(III) from aqueous solution onto iron oxide impregnated activated alumina. Water Qual. Res. J. 2004, 39, 258-266. [CrossRef]

76. Ho, Y.S.; McKay, G. Pseudo-second order model for sorption processes. Process Biochem. 1999, 34, 451-465. [CrossRef]

(C) 2019 by the authors. Licensee MDPI, Basel, Switzerland. This article is an open access article distributed under the terms and conditions of the Creative Commons Attribution (CC BY) license (http:/ / creativecommons.org/licenses/by/4.0/). 